nidade. Acrescente-se, ainda, que a própria faculdade está enfrentando dificuldades de renovar o quadro de professores, a contento, por falta de mestres e doutores.

Argumentar-se-á que faltam instalações adequadas. É verdade, já estão faltando. De fato, não há salas para professores-orientadores ou pesquisadores. Não há salas disponíveis e/ou apropriadas ao ensino diferente do discursivo. Muito menos do que temos, tinham os fundadores da casa. Eles nada tinham e tudo fizeram ou fizemos. Um prédio renovado está ao nosso lado, o da antiga escola Técnica Parobé. É uma questão de negociá-lo com a Faculdad de Engenharia, que está se mudando, com vantagem, para o Campus do Vale. É um sonho nosso, realizável. Se a reitoria aprovar a proposta de novos cursos, e não há porque não aprová-los, as negociações ficam mais fáceis. Cremos que o problema é mais de querer do que de poder.Verdade que parte do prédio ao lado, onde funcionava a Escola Técnica de Comércio já nos foi cedida, para a instalação do Juizado das Pequenas Causas. Mas, é pouco.

\subsection{Conclusão}

$\mathrm{O}$ assunto melhoria do ensino não se encerra e nem se esgota aqui. Volta-se a falar em abolição dos Exames Vestibulares, velho anseio que se choca com o número excessivo de candidatos aos cursos superiores.

Nesta via, a Universidade de Brasília, conforme entrevista do seu reitor pretende convênios com estabelecimentos de $2^{\circ}$ grau: os alunos passarão a ser avaliados durante o curso médio, e em razão desta avaliação prévia, poderão ser dispensados do exame vestibular.

No âmbito do MEC cogita-se da "desconfiança geral" do ensino em nossas universidades, com o ensaio ou ameaça de um "exame final" ou "de ordem", para todos os diplomados com vistas à habilitação ao exercício da profissão, regulamentada, a que fizeram jus em razão do curso em que se diplomaram.

Nem tanto ao mar e nem tanto à terra. Conservar melhorando, no dizer de Júlio de Castilhos, tal é a lei do bom senso.

\section{Notas}

1 Ainda está por ser escrita a saga dos acadêmicos dos anos 50 e 60 , a recepsão dos bixos, as passeatas dos bixos, as discussões sobre a Petrobrás, sobre a morte de Getúlio Vargas, o Chopp do Bar Lider.

2A nossa turma com ingresso em 1954 foi a primeira da Faculdade de Direito a matricular os excedentes: form oferecidas 60 vagas e matricularam-se 85 .

3 Lembre-se a campanha nacional dos educandários gratuitos. Também of fato de o Colégio Estadual Júlio de Castilhosem 1950 ter matrialo didatos arrovatos pefo fomoso atigo 91 siscentos canmas ondeocaros, pelo findoso anigo 9 , instalando turmas onde o curso científico alcan çava a classificação esgotando todo o alfabeto. Nós, por exemplo, conseguimos 4 matricula no primeiro ano científico, na letra o. 4 Padre José Vasconcelos, Presidente do Conselho Fede' ral de Educacãa, in Correio do Povo, de 09 de agosto de 1975 , p.10.

5 Faculdades de Direito da UFRGS, da PUC/RS, da Unisinos, da Ulbra, (Canoas e Gravatai), Ritter dos Reis. 6 Fonte: MEC, relatório do I Seminário Regional dos Cursos Jurídicos.

7 Fonte: MEC, relatório do II Seminário Regional dos Cursos Jurídicos.

8 Fonte: MEC, Relatório do III Seminário Regional dos Cursos Jurídicos.

9 Informaçoeses colhidas na nossa participação e documentos distribuídos durante o seminário. Atéo momento não foram publicados os anais deste encontro.

$10 \mathrm{~A}$ composição do quadro de nossos professores, com sua titulação, está registrada no volume 09, novembro/ 93, da Revista da Faculdade: Memória Institucional, p.10, 93, da Revista

11 Decreto $\mathrm{n}^{\circ} 85.467$, de 10 de dezembro de 1980

12 Resolução no $30 / 91$, UFRGS.

13 Idem, ibidem, artigo 7.

14 Sobre nossa revista, vide Memória Institucional, v.09, novembro/93, p. 15 , item 11.0 .

15 A massa crítica de nossa faculdade compõe-se de 08 doutores, 12 mestres e 09 especializados, idem, ibidem p.10 item 5.4 .

\title{
Autoridade pública e Mandado de Segurança
}

Almiro do Couto e Silva

Professor de Direito Administrativo da Faculdade de Direito da

Universidade Federal do Rio Grande do Sul

\section{Abstract}

Il s'agit d'une étude sur le "mandado de segurança", l'un des plus importants moyens de défense de l'individu à l'encontre de l'Etat.

On y fait l'examen de la notion d'autorité publique et d'acte d'autorité, dont l'existence est necéssaire pour permettre l'utilisation du "mandado de segurança".

La conclusion est que tout acte réglé par le Droit Public est un acte d'autorité, soit - il pratiqué par une personne morale de Droit Public ou par une entitéde l'Administration indirecte del'Etat.

L'orientation dominante va dans un autre sens. Les Tribunaux statuent généralement que les entités de Droit Privé de l'Administration indirecte ne réalisent que des actes de gestion et pas des actes d'autorité. Cette ancienne classification, dont l'origine est française, est dejà presque abandonnée en France. Néanmoins, en droit brésilien, elle est toujours vivante en ce qui concerne le "mandado de segurança". La solution traditionnelle eu comme conséquence, dans le passé, la réalisation des contrats administratifs de grande valeur, sans un appel préalable d'offre à l'admission au service public des personnes qui ont échoué aux concours publics.

On affirme aussi que dans le "mandado de segurança "la partie procédurale c'est la personne morale qui doit subir les conséquences patrimoniales de la décision. Ainsi, le plaideur peut saisir l'autorité judiciaire de son domicile, même lorsque l'autoritéqui a pratiquél l'acte ilégal a son siège ailleurs, par exemple, à Brasilia, sauf, bien entendu, dans les cas où la Constitution a défini la compétence pour statuer sur le "mandado de segurança”.
Ces deux conclusions principales ont pour but de revigorer le "mandado de segurança".

1. Instituído pela Constituição Federal de 1934, o mandado de segurança completou sessenta anos. Nesse período de pouco mais de meio século modificações profundas ocorreram na estrutura da Administração Pública nacional, com a intensificação do processo de descentralização, no qual formas de direito privado foram largamente adotadas. A proliferação das sociedades de economia mista, das empresas públicas e das fundações instituídas ou mantidas pelo Poder Público fez com que parte expressiva da atividade administrativa do Estado passasse a ser exercitada por essas entidades. A nova realidade assim gerada deu causa a que se questionasse o conceito de autoridade pública, contra cujos atos ou omissões ilegais se endereça o mandado de segurança, desde que violadores de direito líquido e certo. Pretende-se examinar, neste trabalho, dois aspectos do instituto do mandado de segurança relacionados com o conceito de autoridade pública. O primeiro prende-se ao direito material, cuidando-se de precisar o que hoje, no estágio atual da experiência brasileira, deverá entender-se por autoridade pública, para fins de mandado de segurança (II). O outro relaciona-se com o direito formal: cogita-se de definir quem é parte no mandado de segurança, tirando-se daí todas as conseqüências no campo processual (III). A resposta que se der a essas indagações poderá ampliar ou restringir, consideravelmente, a importância do mandado de segurança no nosso sistema jurídico. Em muitas hipóteses, dependendo da solução es- 
colhida, ele poderá tornar-se menos útil do que os procedimentos ordinários ou cautelares, previstos no Código de Processo Civil. As conclusões a que chegamos (IV) conduzem, todas, à reafirmação e ao revigoramento do mandado de segurança. dentro do conceito de Estado de Direito, como a ação constitucional por excelência, ao lado do habeas corpus, para a proteção dos direitos subjetivos violados ou ameaçados de lesão pela conduta ilegal ou abusiva de agentes e órgãos do Poder Público, quando atuem ou devam atuar sob regime de direito público, sendo irrelevante a natureza de direito privado das entidades a que se liguem. Dizemos reafirmação e revigoramento do instituto porque jurisprudência dominante reitera, mesmo sob a Constituição Federal em vigor, posições que, sob alguns aspectos, levam à diminuição do mandado de segurança como meio prático endereçado à eficaz garantia dos direitos individuais frente aos atos do Estado, quando estes desbordem dos marcos que lhe são legalmente fixados.

\section{II}

2. A Constituição Federal de 1988, no seu art. $5^{\circ}, \mathrm{LXIX}$, ao definir os traços institucionais do mandado de segurança, declara que ele será concedido "para proteger direito líquido e certo, não amparado por habeas corpus ou habeas data, quando o responsável pela ilegalidade ou abuso de poder for autoridade pública ou agente de pessoa jurídica no exercício de atribuições do Poder Público".

Os antecedentes históricos do mandado de segurança mostram que após algumas hesitações iniciais a respeito de que atos ou omissões seriam por ele impugnáveis, acabou por prevalecer o entendimento, quando da elaboração da Constituição de 1934, que deveriam ser os de "qualquer autoridade", como afinal constou do art. 113, $\mathrm{n}^{\circ} 33$, daquela Constituição ${ }^{1}$.

$\mathrm{Na}$ metade da década de trinta não havia ainda qualquer dificuldade em precisar quem era autoridade pública. Assim considerados

128 eram os agentes das pessoas jurídicas de direito público, das distintas órbitas da federação. Não se iniciara, então, o processo de "fuga para o direito privado" 2 , com a criação de sociedades de economia mista e de empresas públicas, bem como a adoção, com freqüência crescente, de formas e instituições do direito privado para a realização de fins imediatamente públicos. Pode-se dizer que a descentralização administrativa não ultrapassava, então, as fronteiras do direito público, vivendo o Brasil a fase da autarquia. Depois do segundo grande conflito mundial o panorama se altera substancialmente no Brasil, passando o Poder Público a recorrer amiudadamente às sociedades de economia mista e empresas públicas, geralmente para o desempenho de serviços públicos (os chamados serviços públicos de natureza industrial ou comercial), como, por exemplo, os de telefone, de energia elétrica, de gás, de água, etc., mas também para a pura exploração de atividade econômica, em regime de competição com as empresas do setor privado. Mais recentemente, as fundações de direito privado, instituídas e mantidas pelo Poder Público, tiveram seu número notavelmente aumentado, nas diferentes órbitas da Federação.

Nessa fase, autoridade pública era ainda todo aquele que estivesse na posição de órgão de pessoa jurídica de direito público, vale dizer, da União, dos Estados, do Distrito Federal, dos Territórios, dos Municípios e das autarquias. Contra os atos e omissões ilegais desses agentes, violadores de direito líquido $\mathrm{e}$ certo, ou que contivessem ameaça de violação, cabia mandado de segurança. Mas não só. Também era utilizável o mandado de segurança contra os comportamentos ilegais de quem quer que estivesse no exercício de atribuições do Poder Público, quando houvesse lesão ou ameaça de lesão a direito subjetivo.

Ao admitir-se o mandado de segurança contra atos de autoridade pública ou de pessoa que esteja no desempenho de serviço público (ou de atribuições do Poder Público, o que é praticamente a mesma coisa) receberam-se no di-
, brasileiro, pelo menos nas suas grandes as, os critérios historicamente conhecidos direito francês não só para qualificar ceritos jurídicos como atos administrativos, sobretudo para determinar a competênla jurisdição administrativa e da jurisdição um para apreciar atos do Poder Público, inalmente, para distinguir-se entre atos de ito privado e de direito público. Este ponselas consequiências que dele foram e poainda ser tiradas para o direito brasileiro, ece uma análise mais pormenorizada.

?. É sabido que, no direito francês, a prira grande distinção que se estabelece a reso dos atos do Poder Público é entre atos atoridade e atos de gestão. Aqueles, os ato ttoridade, são os que o Estado pratica como ma potentior, investido de prerrogativas e eres que só ele detêm e que os indivíduos, dministrados, não possuem. Só o Esstado e desapropriar, instituir, lançar e arrecadar ostos, encarregar-se do processo civil e peestabelecer e impor limitações e multas inistrativas. Quando o Estado procede a maneira, e o faz no desempenho da funadministrativa, realiza atos de autoridade, são todos atos administrativos e, pois, atos ireito público. Por outro lado, desde o di) romano admite-se que o Estado sujeiteo direito privado, estabelecendo vínculos dicos em condições de igualdade com as ais pessoas, ao gerir o seu patrimônio como quer particular ${ }^{3}$. Esses são os denominaatos de gestão, atos jurídicos de direito pri- celebrados pelo Poder Público. nmann resume, nos seguintes termos, essa as: "Diz-se que a administração está sujeita lireito público quando pratica atos de audade; está sujeita ao direito privàdo por seus os atos, batizados de atos de gestão "4. O rime era de importância manifesta para erminar a competência dos órgãos sdicionais, tendo em vista principalmente a Lei de 24 de maio de 1872 , no seu art. $8^{\circ}$ feria ao Conselho de Estado a competênpara apreciar os recursos por excesso de poder interpostos contra "os atos das diversas autoridades administrativas”. Cabe observar, a esta altura, que o momento político, econômico e cultural era fortemente influenciado pelas concepções liberais. Segundo elas, só em situações absolutamente excepcionais seria de aceitar-se a sujeição do Estado a regime jurídico especial, de direito público e, pois, distinto do regime vigente para os indivíduos em geral. tais situações excepcionais seriam exclusivamente aquelas em que o Estado exercesse, efetivamente, poder público ou autoridade pública, ficando todas as demais subordinadas ao direito privado 5

A transformação do Estado liberal em Estado social, que começa a processar-se a partir da segunda metade do século passado, iria abalar profundamente essa distinção, ao desenvolver rápida e consideravelmente o que a doutrina alemã chama de "administração prestadora de benefícios" (Leistungsverwaltung). No Estado liberal clássico, embora fosse pequeno o tamanho do Estado,este agia preponderantemente por meios coercitivos (administração coercitiva, Eingriffsverwaltung), o que equivale dizer por atos de autoridade, que já dissemos, são sempre atos administrativos. $A$ interferência do Estado no campo econômico e no social, não para impor ou exigir, mas para distribuir vantagens ou benefícios, ou para exercer papel de árbitro, eliminando as desigualdades e procurando estabelecer o equilíbrio entre as forças em confronto dentro da sociedade, acabou por criar um imenso elenco de novos serviços público em que a nota autoritária e coercitiva do Estado, quando não desaparecia de todo, pelo menos ficava grandemente empalidecida. Nesse quadro, tornava-se difícil caracterizar o agente do Estado, distribuidor de benefícios, como autoridade pública e, conseqüentemente, seus atos como atos de autoridade. Não é outra a razão pela qual a doutrina e jurisprudência francesa fixaram a orientação, prevalecente em quase todo XIX, cujas linhas principais foram assim expressas por Berthélémy: “Ato de autoridade é aquele pelo 
qual a Administração ordena ou proíbe alguma coisa. Ato de gestão é o que os administradores realizam, seja em proveito do patrimônio privado (do Estado), seja para o funcionamento dos serviços públicos, nas condições em que os particulares agem na gestão de seus próprios negócios". Ou ainda mais claramente: "Os atos de gestão são aqueles praticados pela administração como representante legal das pessoas administrativas, seja em proveito do domínio privado, seja pelos serviços públicos de que se incumbe"6.

Nas últimas décadas do século passado, notadamente desde o arrêt Blanco, de 1873 inicia-se o processo que resultaria em atribuir ao conceito de serviço público a posição de conceito fundamental e dominante do direito administrativo francês. Para isto muito contribuiu a chamada escola do serviço público, liderada por Duguit, Bonnard, Jèze e Rolland. O triunfo da noção de serviço público fez com que a distinção entre atos de autoridade e atos de gestão entrasse em franco declínio. Não será necessário dizer que a adoção do conceito de serviço público como critério principal para definir a competência da jurisdição administrativa, implicou considerável alargamento do campo de aplicação do Direito Administrativo, que assim ganhou terreno ao Direito Privado. Estendeu-se, também, o conceito de ato administrativo, nele inserindo-se as providências da Administração Pública quando no desempenho de serviços públicos, antes consideradas, como se viu, atos de gestão. Ampliaramse, igualmente, por via de conseqüência, as situações em que os particulares poderiam defender seus interesses frente ao Estado pela via dos recursos utilizáveis na jurisdição administrativa, dentre os quais, pela sua importância, sobressaía e sobressai o recurso por excesso de poder, aliás um dos modelos sobre os quais se formou o instituto do mandado de segurança Mudava-se também, desse modo, o critério para distinguir entre Direito Público e Direito Privado. $O$ rígido contraste entre atos de autori- dade e atos de gestão confinava o campo do Direito público à área em que o Estado se manifestava pela puissance publique. Eram valorizados, nesse contexto, para a fixação do lindes do Direito Público, exclusivamente os meios utilizados pelo Estado e não propriamente os fins por ele perseguidos, como agudamente observou Hauriou 7 . O conceito de serviço público, erigido à condição de critério dominante para traçar-se a summa divisio do Direito, inverteu esse estado de coisas, pois implicou que os fins buscados pelo Estado se tornassem tão ou mais importantes do que os meios por ele empregados. $\mathrm{Na}$ verdade, se os atos praticados pela administração estivessem estritamente vinculados aos fins do Estado (que coincidem, em última análise, com a realização de tarefas de interesse geral, como são os serviços públicos), seriam eles atos administrativos, o que vale dizer, atos jurídicos de direto público, suscetíveis, portanto, de serem atacados perante a jurisdição administrativa, por meio do recurso por excesso de poder. A interpretação jurisprudencial, enriquecida pelas contribuições doutrinárias, acabou por dilatar a noção de autoridade pública - tal como consignada na Lei de 1872, e, posteriormente, pela Ordonnance de 31 de julho de 1945, sobre o Conselho de Estado - para fazer com que assim fossem considerados os agentes de órgãos e entidades da administração pública, ou a ela vinculados, mesmo com personalidade jurídica de direito privado, mas desde que estejam investidos de uma missão de serviço público dotados de prerrogativas de poder público ${ }^{8}$ Contudo, ainda nessas circunstâncias, os atos unilaterais de tais entidades, quando concernentes a relações de direito privado, não se qualificam como atos administrativos 9 .

Desse modo, os atos pertinentes ao funcionamento interno da entidade e sem relação direta com o serviço público constituem atos de direito privado 10 . A lei pode, entretanto, estabelecer exceções. Exemplo disto é a lei de 3 de janeiro de 1973, relativa ao banco da França, atribui competência à jurisdição adminisiva para conhecer dos litígios com os emgados.

Concluem Vedel e Delvolvé que isso im a que os agentes do Banco da França estão metidos ao direito público, enquanto que róprio Banco, apesar das peculiaridades do estatuto e de suas funções, permanece uma soa jurídica de direito privado 11 .

Percebe-se, portanto, que a caracterização zutoridade administrativa, no direito francontemporâneo, é feita por três critérios intos:

(a) - pelo critério dos meios utilizados, quano agente administrativo usa atribuições esíficas do poder público, atuando no exercíde puissance publique

(b) - pelo critério dos fins perseguidos, quano agente administrativo pratica atos estreisente vinculados a serviço público ou deıpenhando uma missão de serviço público (c) - pelo critério legal, quando a norma idica submete ao direito público atos da idade, mesmo que, com relação aos demais, egime seja de direito privado e a própria soa jurídica seja igualmente de direito prilo.

Não será necessário dizer que o recurso ao ério dos meios (a) ou ao critério dos fins (c) será necessário na falta de um critério legal lícito (c). Havendo este, tollitur quaestio, o será ato administrativo e a autoridade que raticar será autoridade administrativa ou oridade pública.

Veremos a seguir que o direito brasileiro, configuração do conceito de autoridade lica, chegou a resultados muitos semelhan aos do direito francês, apesar de a jurispruıcia dominante, mesmo havendo norma de eito público que discipline determinados $s$ de entidades de direito privado da Admitração Pública indireta, persista em afirmar jica e incoerentemente, que esses atos são gestão.

4. Conquanto a Constituição de 1934, no art. $113, n^{\circ} 33$, não houvesse explicitado o que se deveria entender por ato de "qualquer autoridade”, a legislação ordinária posterior, pertinente ao mandado de segurança, cuidou de definir com mais exatidão quais os atos impugnáveis pela nova ação constitucional, traçando, assim, contornos mais nítidos ao conceito de autoridade pública. A lei $\mathrm{n}^{\circ} 191$, de 16 de janeiro de 1936, que por primeiro regulou o processo do mandado de segurança, depois de repetir, no caput do seu art. $1^{\circ}$, o enunciado no texto constitucional, explicitava no parágrafo único: "Consideram-se atos de autoridade os das entidades autárquicas e de pessoas naturais ou jurídicas, no desempenho de serviços públicos, em virtude de delegação ou de contrato exclusivo, ainda quando não transgridam o mesmo contrato". Dava-se, dessa maneira, ao conceito de autoridade pública significado e extensão muito semelhantes, senão idênticos, aos fixados pelo direito francês. O Código de Processo Civil, de 1939, no seu art. $319, \rrbracket 2^{\circ}$, manteve essa orientação, utilizando quase as mesmas palavras ${ }^{12}$. A Consti-

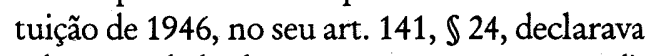
caber mandado de segurança para proteger direito líquido e certo não amparado por habeas corpus, "seja qual for a autoridade responsável pela ilegalidade ou abuso de poder". A Lei n ${ }^{\circ}$ 1.533 , de 31 de dezembro de 1951, no art. $1^{\circ}$, caput, alude a "autoridade, seja de que categoria for e sejam quais forem as funções que exerç". No $₫ 1^{\circ}$ elucida: "Consideram-se autoridade para os efeitos desta lei os representantes ou órgãos dos Partidos Públicos e os representantes ou administradores das entidades autárquicas e das pessoas naturais ou jurídicas com funções delegadas do poder público, somente no que entender com essas funções". A Constituição de 1967, no art. 150, \21, e a Emenda $\mathrm{n}^{\circ} 1$, de 1969, art. 153, $\$ 21$, mantiveram, quanto ao mandado de segurança, a mesma redação da Constituição de 1946.

5. Ao termo dessa evolução e dentro da moldura normativa do art. $5^{\circ}$, LXIX, da atual Constituição e da legislação ordinária em vigor, é de indagar-se o que se deverá entender, 
finalmente, por autoridade pública para efeito de mandado de segurança. A primeira observação a ser feita é a de que a norma da Constituição vigente, relativa ao mandado de segurança, distinguiu entre atos de autoridade pública e atos de agente de pessoa jurídica no exercício de atribuições do Poder Público. Vê-se, assim, no rigor do texto constitucional, que os agentes de pessoa jurídica, no exercício de atribuições do Poder Público, não são mais considerados como autoridade pública, como sempre foram tidos, desde a Lei $n^{\circ} 191$, de 1936 até a Lei $\mathrm{n}^{\circ} 1.533$, de 1951, muito embora con tra os seus atos ilegais, lesivos ou com ameaça de lesão a direito líquido certo, também caiba mandado de segurança, como sempre ocorreu. O discrime, entretanto, tem mais interesse ló gico do que prático. De qualquer maneira, serve para sublinhar que somente autoridade pública realiza ou pratica ato administrativo, no sentido estrito da expressão. Autoridade pública, a seu turno, é todo órgão ou agente de pessoa jurídica de direito público, da administração direta e indireta, das diferentes órbitas da Federação, quando atua sob regime de direito público ${ }^{13}$.

Mas só essas considerações seriam suficientes para demarcar com exatidão a área compreendida pelo conceito de autoridade pública? Parece-me que não. Igualmente os órgãos ou agentes das entidades de direito privado da Administração Indireta, quando praticam atos regidos pelo direito público, são autoridade pública, para fins de mandado de segurança.

6. As entidades de direito privado da assim chamada Administração Pública Indireta raramente estão submetidas a regime puro de direito privado, como é reconhecido universalmente. Geralmente o seu regime jurídico é híbrido: sujeito, em parte e predominantemente, ao direito privado e, em parte, ao direito público. Entre nós, ainda ao tempo da Constituição de 1946, Ruy Cirne Lima expressou como felicidade a posição que inicialmente prevaleceu no direito brasileiro, ao dizer que as relações travadas com a pessoa jurídica ma- triz, portanto quoad intra, eram subordinadas ao direito público e que as relações com os administrados, ou seja, quoad extra, eram sub metidas ao direito privado ${ }^{14}$. Esse entendimento foi reforçado pela regra do art. $170, \mathbb{} 2^{\circ} \mathrm{d}$ Emenda $n^{\circ} 1$ de 1969 , que sujeitava as sociedades de economia mista e as empresas públicas ao mesmo regime jurídico das empresas privadas, notadamente no que respeitava ao Direito do Trabalho e ao das Obrigações. Os atos dos administradores e agentes dessas entidades não seriam, assim, atos de autoridade, passíveis de serem atacados por mandado de segurança. O recurso à ação constitucional só seria admissível contra atos de órgãos de tais pessoas jurídicas quando esses atos estivessem intimamente relacionados com a execução de atribuições públicas delegadas ou, numa fórmula mais simples, de serviços públicos. Fora desta hipótese, os atos seriam todos atos de gestão, para usar a velha classificação francesa, o que é o mesmo que qualificá-los como atos jurídicos de direito privado. Os consectários quer se extraiam dessas premissas eram, entre outros, os de que o acesso aos empregos dessas entidades prescindiam de processo público de seleção de candidatos, mediante concurso e que para a contratação que fizessem de compras, obras e serviços não era exigida licitação. As empresas privadas não realizam concurso para admitir seus empregados nem fazem preceder seus contratos de licitação. Não seria diferente para as empresas públicas e as sociedades de economia mista ${ }^{15}$. A fio de lógica jurídica chegava-se a essas conclusões, sem considerar que uma grande parte dos recursos públicos está hoje em mãos de entidades de direito privado da Administração Pública Indireta, as quais gerem e administram verbas orçamentárias vultuosíssimas. A utilização desses recursos em compras, obras e serviços sem antes efetivar-se procedimento de escolha do outro contratante por critérios tanto quanto possível objetivos, como os da licitação, abria amplas portas a negócios escusos, em que interesses subalternos e até mesmo pessoais dos administradores privilegiados, em detrimento do interesblico. $\mathrm{O}$ que então não se percebia, no , estritamente jurídico, é que toda a Adtração Pública, seja ela Direta ou Indireter se realize por pessoas jurídicas de dipúblico ou de direito privado, está jungida incípio da igualdade. A igualdade, imposlo princípio constitucional não significa mente igualdade perante a lei ou na lei, nda perante os serviços públicos, mas há entendida, antes e sobretudo, como igualperante o Estado. A incidência do princía igualdade, nessas hipóteses e situações, , condão não apenas de afastar dessa área sito privado, substituindo-o pelo direito co, como também o de transformar, obente, os atos jurídicos nesse campo pratiem atos administrativos, atos jurídicos eito público, descaracterizando-os como $s$ atos de gestão, regidos pelo direito priDito de outro modo, são eles atos de idade, para fins de mandado de seguranjis não se pode aceitar, sem afronta à lógiaos próprios fundamentos do Direito inistrativo, que atos jurídicos unilaterais, reito público - atos administrativos, por- praticados por órgão de entidade da inistração Pública Indireta, não sejam atos toridade. O regime híbrido, tradicionale admitido como sendo próprio das enti; de direito privado da Administração ica Indireta, tem, assim, sua parte de dipúblico acrescida pelos princípios consionais balizadores de toda a atividade adstrativa, dentre os quais realça-se especiale o da igualdade.

'reio que a Constituição de 1988 veio por is divergências que ainda subsistiam ao ıeter toda a Administração Pública, "diindireta ou fundacional, de qualquer dos res da União, dos Estados, do Distrito ral e dos Municípios", aos princípios enudos no seu art. 37, entre os quais estão o de "a investidura em cargo ou emprego ico depende de aprovação prévia em con, público de provas ou de provas e títu- los" e o de que "ressalvados os casos especificados na legislação, as obras, serviços, compras e alienações serão contratados mediante processo de licitação pública que assegure igualdade de condições a todos os concorrentes, com cláusulas que estabeleçam obrigações de pagamento, mantidas as condições da proposta, nos termos da lei, o qual somente permitirá as exigências de qualificação técnica e econômica indispensáveis à garantia do cumprimento das obrigações" (inciso XXI).

Assim, como se não bastasse a referência genérica aos princípios de legalidade, impessoalidade, moralidade e publicidade, feita no caput do art. 37, entendeu o legislador constituinte, ainda, de consignar expressamente a obrigatoriedade de realização de concurso público para investidura em cargos e empregos públicos, bem como de procedimento licitatório em todas as esferas do Poder Público. Neste particular, portanto, todas as entidades da Administração Pública, quer tenham personalidade jurídica de direito público ou de direito privado, ficaram submetidas ao Direito Público. É evidente, portanto, que os atos jurídicos que seus agentes praticarem, no iter do procedimento licitatório ou do concurso público, são atos de direito público, atos administrativos, atos de autoridade e não atos de gestão, que são sempre e necessariamente de direito privado.

As considerações até aqui desenvolvidas permitem concluir que, atualmente, autoridade pública, para efeitos de mandado de segurança, são (a) os agentes ou órgãos das pessoas jurídicas de direito público e (b) os das entidades de direito privado da Administração Indireta ou fundacional, para usar a linguagem da Constituição, em ambas as hipóteses quando atuem sob regime de direito público, praticando atos administrativos. As pessoas jurídicas de direito público atuam, normalmente, sob regime de direito público e só excepcionalmente sob regime jurídico de direito privado (por exemplo, quando celebram contrato de locação, como qualquer particular). Quando assim 
procedem, sob regime de direito privado, os atos que realizam são de gestão e não de autoridade. Exatamente o inverso sucede com as entidades de direito privado da Administração Indireta. Os atos que praticam são, em larga medida, sujeitos a regime de direito privado só em caráter de exceção são disciplinados pelo direito público. Enquadram-se nesta última hipótese os atos previstos em normas jurídicas de direito público, como sucede com os integrados em procedimentos licitatórios e de concurso público, bem como os diretamente vinculados a serviço público.

7. Conclui-se, portanto, que o elemento chave para a caracterização de autoridade pública para fins de mandado de segurança é o regime jurídico a que está sujeita a relação jurídica em que atue. Se esse regime for de direito público, o ato que praticar será de autoridade, se for de direito privado, o ato será de direito privado ou de gestão 16

É induvidoso, pois, que a atual Constituição da República, ao estender suas normas às entidades de direito privado da Administração Indireta, ampliou notavelment o campo de abrangência do mandado de segurança, transformando certos atos praticados pelos agentes e órgãos dessas entidades, de ato de gestão que eram, em atos de autoridade.

8. A jurisprudência, entretanto, tem resistido, mesmo sob a Constituição de 1988, em aceitar, que os atos praticados por agentes de entidades de direito privado da Administração Indireta em procedimentos licitatórios ou de concurso público - para ficar só nas hipótese mais comuns de atos de órgãos dessas entidades regidos pelo direito público - sejam atos de autoridade e não atos de gestão, como dominantemente eram considerados anteriormente ${ }^{17}$. Parece ter ocorrido nessa matéria, como tantas vezes sucede, um efeito de inércia, que empurra o direito antigo para dentro do direito novo, num primeiro momento encobrindo-o e suplantando-o. Com o tempo, porém, começam a ser percebidas as distinções bem marcadas entre uma situação e outra.

As regras constitucionais que agora, explícita e induvidosamente, incidem sobre os atos

134 de agentes de entidades de direito privado da Administração Indireta qualificam-nos imediatamente como atos jurídicos de direito público. Essa circunstância - a de serem atos de direito público - impede terminantemente que sejam tidos e havidos como atos de gestão, pela simples e definitiva razão que os atos de gestão são sempre e invariavelmente atos de direito privado, aqui e em qualquer outro sistema jurídico.

Afirma-se que existem atos de gestão de direito público (ou, o que é o mesmo, disciplinados ou regidos pelo direito público) é uma contradição nos seus próprios termos e uma agressão à lógica tão estridente como dizer que o círculo é quadrado.

$\mathrm{Na}$ verdade, no regime anterior, quando determinado ato de entidade de direito privado da Administração Indireta era classificado como ato de gestão pretendia-se com isto significar que tal ato não estava vinculado diretamente a serviço público, pois só ato com essas características é que poderia ser atacado por mandado de segurança, uma vez que sua ligação com um serviço público o arrastava imediatamente para o campo do Direito Público. Sendo a entidade de direito privado e não ostentando o ato praticado por seus agentes estreita relação com um serviço público, ficava claro que a sua natureza era de ato jurídico de direito privado e, portanto, de ato de gestão. O reconhecimento da incidência do princípio da igualdade, em todas as suas variantes, sobre os atos das entidades de direito privado da Administração Indireta, primeiro na doutrina e, agora, por imposição da Constituição Federal, alterou completamente esse estado de coisas, como tive ocasião de mostrar.

Assim, os atos das entidades de Direito Privado da Administração Pública Indireta estão submetidos ao direito público em duas hipóteses: (a) quando sejam atos de autoridade, isto é, quando sejam atos regidos ou disciplinados diretamente por norma de direito público, muito embora não tenham ligação direta com o serviço público, e (b) quando estejam vinculados a serviço público. A primeira hipótese compreende atos que expressam ativi- 3-meio, mas que, não obstante isto, sujei-se a regime jurídico especial, de direito lico. Os exemplos mais comuns são os atos icados nos procedimentos de concurso lico ou de licitação pública. A segunda hisse compreende os atos praticados no exer, de atribuições públicas delegadas, que são pre atividades-fim. Conforme se verifique l ou outra hipótese, diversa será o órgão Poder Judiciário competente para examias eventuais controversias. Ilustremos isto 1 um exemplo, que se desdobra em duas ações. Primeira: sociedade de economia ta estadual, concessionária de serviço púo federal, ao realizar concurso público para tratação de empregados viola direito subro de um dos candidatos. A justiça compee para apreciar o mandado de segurança - a estadual. Segunda: a mesma sociedade de nomia mista, no desempenho do serviço lico federal, de que é concessionária, tiliza direito subjetivo de usuário. A justiompetente para apreciar o mandado de seança será a federal.

A manutenção da orientação sprudencial que vê nos atos praticados nos cedimentos licitatórios e de concursos púos das entidades de direito privado da adlistração indireta simples atos de gestão, $\mathrm{n}$ de incidir no ilogismo antes verberado aceitar a existência de atos de gestão de dio público, tem ainda o inconveniente de uzir substancialmente a abrangência do ndado de segurança. É notório que, hoje, :nsas obras pública são realizadas por emsas públicas e sociedades de economia misA maior parte as barragens, para ficarmos n exemplo expressivo, são construídas por soas jurídicas que têm essa natureza. Se, tra os atos dos administradores dessas entiles, no procedimento licitatório, ficar exída a possibilidade de impetração de manlo de segurança, é óbvio que se estará redudo a importância do mandado de seguransomo meio constitucional adequado para nbater as ilegalidades e abusos do Poder Jlico que lesam ou ameaçam de lesão os dios subjetivos públicos dos administrados.
E nem se diga, como já tem sido asseverado em contraposição a esse argumento, que ao particular lesado estará sempre aberto o caminho da ação cautelar e da ação ordinária, para a proteção de seus interesses. A explicação não procede, por uma razão muito simples. No mandado de segurança não há sucumbência do impetrante precisamente para que não seja criado obstáculo ou embaraço à utilização da ação constitucional, como garantia que se quer a mais ampla possível. $\mathrm{O}$ mesmo não ocorre entretanto, nas ações cautelares e ordinárias. Ademais, na ação cautelar, responde o autor pelos prejuízos que causar na execução da liminar, nas hipóteses previstas no art. 811 do Código de Processo Civil. Assim, vencido o autor em cautelar em que pleiteou e obteve liminar determinando a sustação da assinatura do contrato de obra pública com licitante que considerava indevidamente classificada em primeiro lugar, estará obrigado indenizar os prejuízos, freqüentemente vultosíssimos, relacionados com o atraso do início da construção. Será, em suma, penalizado pela utilização de legítimos meios processuais de defesa de seus direitos perante o Estado, o que, no mandado de segurança, não se verificaria. Tem-se, dito escrito, a esse propósito, que tal tipo de raciocínio não é científico e nem jurídico. Não me parece que sejam assim. $\mathrm{O}$ mandado de segurança foi concebido como o mais amplo, direto, pronto e expedito meio de fazer valer os direitos subjetivos públicos dos indivíduos, quando atropelados ou ameaçados de lesão por autoridade pública ou por pessoa jurídica investida de atribuições do Poder Público. Como instituto de direito constitucional que é e com a natureza que tem de garantia fundamental, há de ser interpretado segundo os cânones exegéticos que comandam a intelecção e interpretação das mais altas normas existentes no ordenamento jurídico nacional.

Quer pela interpretação sistemática da Constituição, quer pela interpretação teleológica, que coincide com a que a moderna doutrina americana tem chamado de responsive interpretation - reconhecidamente os mais eminentes e prestigiados métodos de in- 
terpretação - a conclusão a que se chega é a mesma.

$\mathrm{Na}$ verdade, não teria sentido, dentro do sistema da Constituição de 1988, que à sujeição das entidades de direito privado da Administração Indireta aos princípios discriminados expressamente no art. 37 , não tivesse contrapartida - quando esses mesmos princípios fossem violados e a violação implicasse lesão ou ameaça de lesão a direito líquido e certo dos indivíduos - na possibilidade de utilização do mandado de segurança, como instrumento por excelência para obter-se, a um só tempo, a recomposição da fratura causada à ordem constitucional e a preservação do direito individual.

Percebe-se que, de outro modo, sistema constitucional seria extremamente falho, imperfeito, desequilibrado e assimétrico.

Teria avançado ao submeter as entidades de direito privado de que o Estado se serve para a consecução dos seus objetivos aos grandes princípios a que deve ater-se a Administração Pública em geral e, ao mesmo tempo, revelaria inexplicável timidez ao fechar a via do mandado de segurança a quem tivesse direito subjetivo hostilizado ou ameaçado por ato ou omissão que contrariasse aqueles mesmos princípios.

A Constituição há de ser vista e entendida como uma unidade harmônica, devendo sua interpretação contribuir para a mais completa realização possível dessa unidade, de sorte que as diferentes partes se esclareçam e iluminem reciprocamente, a fim de que os contrastes, as aparentes incongruências, as dificuldades lógicas sejam aplainadas, superadas ou eliminadas em proveito do todo, encurtando-se, assim, ao máximo, a distância que a separa da perfeição 18 .

Por outro lado, se visualizada a Constituição numa perspectiva finalista ou teleológica, há de responder e corresponder, como tem assinalado a mais recente doutrina norteamericana, ao "ethos nacional", à "experiência do país", ao "caráter fundamental" e ao "objetivos da nação"19. Sob este ângulo, a norma constitucional só pode ser compreendida "como função da sociedade no instante da aplicação do direito" 20

Ora, a negação da utilização do mais nobre e importante meio de proteção dos direitos individuais não amparados pelo habeas corpus contra o arbítrio e os abusos do Pode Público, quando este assume forma de direito privado, mas atua no campo do direito público, não estaria em consonância com o sentimento e a opinião geral da sociedade, que se identificam com as aspirações da nação. $\mathrm{Nada}$ justificaria, nesse contexto, que a Administração Pública, procedendo de idêntica maneira como se comportam suas entidades de direito público, tivesse seus atos imunes ao mandado de segurança. Que isso ocorra nas situações em que as entidades de direito privado da Administração Pública indireta agem sob normas de direito privado é perfeitamente compreensível. Mas é inaceitável a mesma solução nos casos em que essas mesmas entidades atuam sob regras de direito público. A extensão das regras de direito público a certos atos por elas praticados - o que resulta, em algumas hipóteses, de imposição constitucional - demonstra, por si só, a presença de interesse público particularmente denso e significativo. É evidente que se não houvesse tal interesse, não haveria porque sujeitar aqueles atos a regime jurídico especial de direito público. Sendo idêntico o regime jurídico dos atos das entidades de direito público e o de certos atos das entidades de direito privado, idêntico deverá ser, também, o sistema de proteção e defesa dos direitos individuais em ambas as circunstâncias. Não se trata apenas de uma exigência lógica, como já se viu, mas de uma exigência também da sociedade numa fase da vida nacional em que a efetiva realização dos princípios constitucionais, como o da igualdade, o da moralidade, o da impessoalidade, o da legalidade, que se unem para compor o perfil do Estado de Direito, é diariamente cobrada pela opinião pública. A ratio legis e o fim, o telos, da norma constitucional, extraem-se a cada momento da experiência histórica. É isto que faz da Constituição um documento vivo, sempre adaptado ou adaptável às mutações políticas, econômicas, is ou culturais. Os institutos previstos na itituição, como o mandado de segurança, de ser entendidos e interpretados, objeti'nte, dentro dessa mesma tendência de zimação entre os fatos e a norma, num ssso dialético permanente. À alteração dos deverá muitas vezes corresponder uma ıção do conteúdo da norma, da mesma sira que esta exercerá freqüentemente uma conformadora sobre os fatos. A leitura onstituição anterior sob a pressão de falamorosos, que agrediam duramente a ziência nacional, como a contratação de sas obras públicas sem licitação ou o ino de empregados sem a prestação de cons público, conduziu ao entendimento, ntado por autorizada doutrina como reaเ orientação até então dominante, de que tidades da Administração Pública indiresm personalidade de direito privado, estaobrigadas a realizar certames públicos para itratação de obras e serviços, bem assim o para a admissão de pessoal, pela incidênos princípios da igualdade e da moralidade ica. A Constituição atual tornou explícita imposição. Não há, pois, como ainda disa qualificação dos atos dos órgãos e agenúblicos das entidades de direito privado dministração Pública indireta como atos utoridade, quando se sujeitem a regime lico de direito público.

istas conclusões valem tanto para as entis de direito privado da Administração ica que prestem serviços públicos, que n eles administrativos, comerciais ou in iais, quer para as outras que desempenham atividade econômica. O Estado só excepalmente pode explorar atividade econômqual "só será permitida quando necessária imperativos da segurança nacional ou a rante interesse coletivo, conforme definiem lei" (CF, art. 173).

á se pretendeu que os preceitos do art. 37 instituição Federal, na parte atinente às tades de direito privado da Administração reta, só seriam aplicáveis àquelas que pres:m serviço público. As demais estariam ramente sujeitas a regime de direito priva- do, por força do que estatui o $\mathbb{1} 1^{\circ}$ do art. 173 da Constituição Federal: "A empresa pública, a sociedade de economia mista e outras entidades que explorem atividade econômica sujeitam-se ao regime jurídico próprio das empresas privadas, inclusive quanto às obrigações trabalhistas e tributárias". Contudo, a distinção entre entidades de direito privado da Administração Pública prestadoras de serviços públicos e não prestadoras de serviço público (entre estas estariam, é claro, as que exploram atividade econômica) só aparece, no texto do art. 37 , no seu $\llbracket 6^{\circ}$, que cuida da responsabilidade extra-contratual do Estado. Bem se vê, pois, que não é exclusivamente a vinculação direta a um serviço público que atribui natureza de direito público aos atos dos agentes das entidades de direito privado da Administração Pública Indireta. Idêntica natureza terão os atos dos agentes dessas entidades quando forem regidos e disciplinados pelo Direito Público, como é o caso dos realizados nos procedimentos licitatórios e de concurso público. Em tais hipóteses, a condição de ato administrativo, ou de ato de autoridade, para efeito de mandado de segurança, provém diretamente da norma jurídica e não da circunstância de estar o ato relacionado intimamente com a prestação de serviço público. E a primeira das normas jurídicas existentes no nosso sistema, a esse propósito, é de natureza constitucional e está cristalizada no art. $37 \mathrm{da}$ Constituição Federal, nos incisos II e XXI. É absolutamente irrelevante, pois, quanto às licitações e concursos públicos, o tipo de atividade que as entidades de direito privado da Administração Pública Indireta exerçam. Quer sejam prestadoras de serviços públicos, quer se dediquem à atividade econômica, seus atos serão, nesses particular e dentro desses limites, atos de direito público, atos administrativos ou atos de autoridade. Isto importa afirmar que são passíveis de ataque por mandado de segurança.

\section{III}

9. Outra importante questão, sobre a qual ainda se controverte na doutrina e na jurispru- 
dência, é se a autoridade pública a quem se imputa conduta abusiva ou ilegal, ensejador da impetração do mandado de segurança, seria, ou não, parte no processo. A discussão antiga e remonta às próprias origens do man dado de segurança, pois no art. 113,33 , da Constituição de 1934, depois de afirmar-se que se daria mandado de segurança "para a defesa de direito, certo e incontestável, ameaçado ou violado por ato manifestamente inconstitucional ou ilegal de qualquer autoridade", acrescentava-se: "O processo será o mesmo do habeas corpus, devendo ser sempre ouvida pessoa de direito público interessada". Quem seria, então, parte na ação de segurança? A autoridade coatora? A pessoa de direito público interessada? Ambas?

A Corte Suprema, que assim se chamava ao tempo da Constituição de 1934, examinando a questão em agosto daquele mesmo ano dividiu-se em três correntes. Uma, a majoritá ria, orientou-se no sentido de que deveriam se ouvidas na ação a autoridade de quem emanou o ato, como ocorre no babeas corpus, e o Procurador Geral da República, na qualidade de órgão da União. Outra entendia que só o re presentante da União deveria ser ouvido. E uma terceira, que só a autoridade coatora. A Lei n ${ }^{\circ} 191$, de 16 de janeiro de 1936, dispunh que, conhecendo do pedido, o juiz mandaria citar o coator e encaminharia, por ofício, ao representante judicial ou legal da pessoa jurídica de direito público interno, interessada no caso, a terceira via da petição inicial com a respectiva cópia dos documentos. Dispunham além, que na contrafé da citação e no ofício seria fixado o prazo de dez dias, para a apresentação da defesa e das informações reclama-

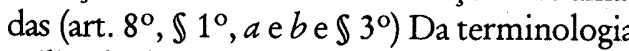
utilizada depreende-se que o legislador, ao referir-se à citação da autoridade coatora, considerava esta parte na ação. No que concerne, porém, à pessoa de direito público interno interessada no caso, a lei não preceituava que fosse ela citada, conquanto determinasse sua ciência da demanda pela cópia da petição inicial e da documentação a esta anexada, para que pudesse apresentar sua defesa. Ora, só se defende quem é parte na ação. Outras disposições tornam inequívoca a condição de parte que tem a pessoa jurídica de direito público interno interessada no caso. Assim a que ordena que, julgando procedente o pedido, o juiz a ela transmitirá, em ofício, o inteiro teor da sentenca, para que a cumpra imediatamente (art. 10 "a" e parágrafo único). Do mesmo modo a que declara que o recurso poderá ser interposto "pelo imperante, pela pessoa jurídica de direito público interessada e pelo coator" (art. 11 ${ }^{\circ}$ \$) - reforçando a qualidade de parte da autoridade coatora, que ficara empalidecida com a ausência de obrigatoriedade de lhe serem comunicados os termos da sentença concessiva da segurança $\left(\operatorname{art.} 10^{\circ}\right)$.

O código de Processo Civil de 1939, no art. 322, dispunha que o juiz, ao despachar a petição inicial, deveria notificar o coator, "a fim de prestar informações no prazo de dez dias" (inciso I) e citar "representante judicia ou, à falta, o representante legal da pessoa jurí dica de direito público interessada na ação" (inciso II). Julgado procedente o pedido, $o$ inteiro teor da sentença era transmitido ao representante legal da pessoa jurídica de direito público interessada (e não ao coator), nos termos do art. 325, I, para que a cumprisse, sob pena de desobediência (art. 327). O representante da pessoa jurídica de direito interessada era, também, o único legitimado para reque rer ao presidente Supremo Tribunal Federa ou do Tribunal de Apelação, conforme a competência, autorização para a execução do ato impugnado, para enviar lesão grave à ordem, à saúde ou à segurança pública (art. 327). No CPC anterior, portanto, a autoridade coatora não tinha sua posição bem definida na ação. Era notificada para prestar informações e, após estas, não tinha mais participação no manda do de segurança. Quanto a quem poderia recorrer, a lei nada dizia, sendo de inferir-se, entretanto que apenas a pessoa jurídica de direito público interessada tinha essa faculdade, pois, como se viu, também só ela tinha legitimação para pleitear junto ao presidente do Supremo Tribunal Federal ou do Tribunal de Apelação quando verificadas as hipóteses legalmente de- as, a autorização para executar o ato imıado, após ter sido prolatada sentença essiva da segurança.

1 Lei n ${ }^{\circ} 1.533$ de 31 de dezembro de 1951 teve a ambigüidade e as vacilações que semxistiram em nossa legislação na determio de quem é parte no mandado de segua, indecisão que deu azo a acesas discusna doutrina. Declara a lei vigente que, ao achar a inicial, o juiz ordenará a notificado coator do conteúdo da petição, para preste as informações que achar necessárirt. $7^{\circ}$, I). A pessoa jurídica de direito pú, interessada só é mencionada no art. $2^{\circ}$, tem este enunciado:

Considerar-se-á federal a autoridade ora, se as consequiências de ordem monial do ato contra o qual se requer o dado de segurança houverem de ser supor¡pela União ou pelas entidades autárquicas rais".

Zuando julgado procedente o pedido, n é notificado da sentença é a autoridade ora. Apesar do relevo dado à autoridade ora na atual lei do mandado de segurança, mo assim a praxe judicial consolidou ndimento, pode-se dizer que indiscrepante, ue a participação da autoridade coatora na praticamente resume-se a ser notificad prestar informações, a efetivamente prestáie assim entender, e a ser notificada da sena concessiva do mandado. A competência rsal é da pessoa jurídica de direito público ressada. A autoridade coatora não pode rrer, do mesmo modo como não pode faiustentação oral.

Jiante dessas circunstâncias será de pergun;e a razão não estaria com Pontes de anda quando sinteticamente afirmava que andado de segurança é impetrado contra o io e não contra a pessoa jurídica de direito lico, mas que esta é a demandada 21 . Celso ícola Barbi critica essa posição por julgá-la recisa ${ }^{22}$. Não percebemos, porém, onde ria a imprecisão. Se a pessoa jurídica é a landada ela é a parte. No entanto, o man$\checkmark$ de segurança tem um endereço imediato, é o de afastar a lesão ou a ameaça de lesão a direito individual que órgão da parte praticou ou está prestes a praticar, por sua ação ou omissão. Por isto é que o mandado de segurança é requerido para proteger o autor contra a conduta comissiva ou omissiva, não da parte ré como um todo, mas especificamente do órgão de onde proveio a violação ou a ameaça de violação de direito subjetivo do demandante, como tem sido repetido por todas as nossas Constituições Federais, desde a de 1934. Assim, razões de ordem prática, que visam a dar presteza e funcionalidade operacional ao instituto do mandado de segurança, é que determinaram que o órgão, que não é a parte, é que seja notificado para prestar informações. $\mathrm{N}$ verdade, tecnicamente, não se cuida de simples notificação, mas de verdadeira citação, como bem percebeu Seabra Fagundes 23 . Por igual, as informações prestadas pelo coator são a defesa da pessoa jurídica de que ele é agente ou órgão. Fica claro, portanto, que não há qualquer litisconsórcio entre a pessoa jurídica interessada e o seu órgão, cujo comportamento deu ensejo à impetração do mandado de segurança. Não há, aí, duas partes, mas uma só, a pessoa jurídica, que é citada e se defende por seu órgão, consoante disposição legal. (Theotônio Negrão, p. 1109).

10. Fixada a posição de que parte é a pessoa jurídica de que o coator é órgão, cabe extrair dessa premissa todas os consectários, alguns dos quais são extremamente importantes para a definição da competência jurisdicional para apreciar o mandado de segurança. É sabido que essa competência tem sido determinada pela órbita a que pertence a autoridade coatora pela sua localização territorial, fora dos caos expressamente estabelecidos nas Constituições e nas leis. $\mathrm{Na}$ verdade, a jurisprudência tem acentuado que "a competência para apreciar o mandamus define-se pela autoridade apontada coatora"24. Torna-se desde logo perceptível que essa orientação traduz as já mencionadas vacilações existentes no direito nacional quanto ao papel que desempenha no processo a autoridade coatora, refletido de modo muito claro a concepção de que ela seria parte na ação A regra sobre competência territorial, no per- 
tinente às ações pessoais e as ações reais sobre móveis, é a de que ela se determina pelo domicílio do réu (CPC, art. 94). No que se refere à União, quando for autora, ré ou interveniente, será competente o foro da capital do Estado ou do Território (CPC, art. 99). Essa idéia foi reforçada pelo art. $109, \mathbb{} 2^{\circ} \mathrm{da}$ Constituição Federal, cujo enunciado demonstra a clara intenção do legislador constituinte em proteger - particular: "As causas intentadas contra a União poderão ser aforadas na seção judiciária em que for domiciliado o autor, naquela onde bouver ocorrido o ato ou fato que deu origem à demanda ou onde esteja situada a coisa, ou, ainda, no Distrito Federal". Diante da limpidez desse texto, é inaceitável que os tribunais continuem a exigir, no mandado de segurança, que ele deva ser impetrado no foro da autoridade coatora. Ora, as mais importantes autoridade da União têm sede, geralmente, em Brasília. Seus atos ou omissões, entretanto, podem lesar ou ameaçar de violação direitos subjetivo de pessoas que vivem nos mais diferentes pontos do território nacional. A muitas dessas pessoas estaria vedado o acesso ao mandado de segurança, nessas circunstâncias, pelas dificuldades de toda ordem que teriam para propor ação constitucional em Brasília. A elas só estaria a via das ações ordinárias ou das ações cautelares para a defesa do seu direito, com todos os riscos, ônus e inconvenientes inerentes a essas ações, alguns dos quais já foram aqu realçados. Com isto, acaba-se por proteger muitas vezes, o autoritarismo do Estado, a ile galidade e o comportamento abusivo do Poder Público, pela diminuição fática ou material da possibilidade de controle dos seus ato pelo Judiciário. Com isto, também, acaba-se por comprometer a própria realização do Estado de Direito que, como se sabe, é uma obra em contínua elaboração, sempre imperfeita mas que há de tender sempre para a perfeição. Um dos objetivos mais eminentes do Estado de Direito é a realização da justiça material. $O$ princípio do Estado de Direito, acolhido destacadamente logo no art. $1^{\circ}$ da nossa Constituição Federal, serve como regra de ouro para a interpretação dos demais princípios e nor- mas constitucionais ou da legislação ordinária. Desse modo, as garantias constitucionais, entre as quais está a do mandado de segurança, deverão ser compreendidas de modo a assegurar, da maneira mais completa possível, a aproximação entre o Estado de Direito que temos com o Estado de Direito com que sonhamos.

Creio que a conformação do mandado de segurança pelo princípio do Estado de Direito deverá conduzir a que se admita sua impetração contra atos ou omissões de autoridades da União, para cujo exame a Constituição não tenha estabelecido competência especial, de acordo com a norma do $109, \mathbb{2} 2^{\circ}$ da Constituição Federal. Milita também em favor dessa solução o entendimento hoje francamente dominante de que no mandado de segurança é a pessoa jurídica interessada e não seu órgão, de onde proveio a coação ou a ameaça de coação. Se a União é que é a parte no mandado de segurança requerido contra ato ou omissão de agente seu, não há razão lógica para que a competência jurisdicional seja determinada pelo local onde tem sede a autoridade coatora, como se tem decidido reiteradamente. A exegese prevalecente beneficia a pessoa jurídica interessada ou a autoridade coatora, que é seu órgão, em detrimento ou desfavor de quem sofreu ou está ameaçado de sofrer lesão em direito subjetivo de que é titular. Este é que é o destinatário da garantia constitucional, e não o Poder Público. E aquela interpretação tem servido, também, a manipulações e desvios realizados pelo Poder executivo, com o fito de dificultar ou até mesmo, em muitas situações, de impossibilitar a impetração do mandado de seguran$\mathrm{ça}^{25}$.

Para arrumar estas observações de modo mais concentrado ou sintético, pode-se dizer que entre duas interpretações, uma que limita, cerceia ou restringe a utilização do mandado de segurança, e outra mais generosa e liberal, que lhe dá dimensão mais dilatada, esta última deverá ser a preferida, por três razões principais. A primeira resulta da própria amplitude do texto constitucional que desenhou o instituto do mandado de segurança como garantia em duplo sentido: como garantia institucional, indo o conceito clássico de Carl Scmitt, e to garantia dos sujeitos de direito contra ; ou omissões ilegais de qualquer autoridasública ou de qualquer agente de pessoa juca no exercício de atribuições do Poder lico. A segunda deriva da necessidade, já ntada, de harmonizar o mandado de seguça com princípio do Estado de Direito. E a eira consiste na orientação entre nós firda de que a pessoa jurídica e não o órgão, a oridade coatora, é que é parte no mandado iegurança.

Assim, resumindo tudo num exemplo, se ttoridade federal tiver sede em Brasília e não daquelas cujos atos ou omissões que vioI ou ameacem violar direitos subjetivo ejem a impetração de mandado de seguran :m foro privilegiado ou especial (p. ex. Presnte da República, Ministro de Estado, etc) ão de segurança deverá ser proposta na ca1 do Estado, conforme o art. 109, $\int 2^{\circ} \mathrm{da}$ nstituição Federal e não em Brasília.

Parece-me que é este um dos modos de resir ao mandado de segurança a sua dignidaoriginal, comprometida pelas dificuldades todo o gênero que a ale são opostas, o que , em contrapartida, servido para aumentar restígio e a eficácia prática das ações telares, para as quais inexistem muitas das ridas, perplexidades e indefinições que cer1 a ação constitucional.

\section{IV}

As reflexões desenvolvidas induzem a que onclua que o mandado de segurança, sob a nstituição de 1988, é cabível contra qualr agente da Administração Pública, direta indireta, quer a entidade de que seja órgão ha personalidade de direito público ou de aito privado, desde que o ato ou omissão ,al a ele imputada seja disciplinado ou regi pelo direito público. A orientação isprudencial que considera atos praticado concurso público ou em procedimento licitatório, por agentes de entidades de direito privado da Administração Pública Indireta, como atos de gestão e, pois, de direito privado, não pode prevalecer diante das normas constitucionais e da legislação ordinária vigentes que têm natureza de direto público. Tal posição seria ainda sustentável antes da entrada em vigor da atual Constituição da República, mas nunca depois dela, em face da clareza do seu texto. Incorporou-se, desse modo, ao território do mandado de segurança um número altamente expressivo de comportamentos comissivos e omissivos do Poder Público, quando atua por suas entidades de direito privado, mas segundo preceitos de direito público, robustecendo-se, por conseqüência, a ação constitucional que é, por sua vez, como tantas vezes realçado, uma garantia institucional.

Complementa-se, de outra parte, o revigoramento do mandado de segurança, que começava a debilitar-se pela voga das ações cautelares e ações principais, favorecidas por algumas vantagens importantes (desnecessidade de indicar com precisão a autoridade coatora, possibilidade de propô-las contra a União, em consonância com as regras processuais ordinárias, determinadoras da competência jurisdicional) ao extrairem-se todas as derivações jurídicas da noção, hoje francamente dominante, de que parte no mandado de segurança não é nunca a autoridade coatora, mas sim a pessoa jurídica de que ela é órgão. Nessa conformidade, quando a autoridade coatora for órgão da União e inexistir regra jurídica explícita que determine a competência jurisdicional pelo lugar onde tenha sede, competente será a Justiça Federal da capital dos Estados e Territórios, caso estes últimos venham a ser criados.

O redirecionamento dos rumos da jurisprudência em ambas as hipóteses focadas, de direito material e de direito formal ou processual, produzirá o benéfico efeito de repor o mandado de segurança no lugar de singular destaque que lhe pretendeu dar o legislador constituinte e que a Constituição, que é o que realmente importa, efetivamente lhe reservou. 
Notas

1 Ao tempo da Constituição de 1891 , a Lei no 221 , de 1894 criou uma ação especial para a invalidação dos atos da administração lesivos de direitos individuais. Tal ação, entretanto, teve escassa importância na defesa dos direitos individuais contra atos do Poder Público. Como é bem conhecido, nesse período o habeas corpus e as ações possessórias é que desempenham a função de proteger os particulares contra os atos ilegais ou abusivos praticados pelos agentes do Estado. A descaracterização do habeas corpus como ação endereçada exclusivamente a atacar qualquer cerceamento da liberdade individual pelo Poder Púte em instrumento de proteção de direitos de outra natute em instrumento de proteção de direitos de outra natureza, especialmente os patrimoniais, e a aceitaçâo de que a posse poderia ter como objeto também bens incorpóreos, como os direitos, foram as vias então encontradas para estabelecer um razoável sistema de defesa dos individuos com relação às providências ilegais do Estado. Contudo, já em 1914, no seu livro $A$ Organizasão Nacional, Alberto Torres propunha a criação de um "mandado de garantia", para proteger direitos "lesados por atos do Poder Públi$\mathrm{co}$, ou de particulares, para os quais não haja outro recurso especial" (Rio de Janeiro, Imprensa Nacional, 1914, p. 367). A reforma constitucional de 1926 reconduziu o babeas corpus aos seus limites clássicos, deixando um vácuo que o deputado Gudesteu Pires tratou logo de preencher, ao apresentar no Congresso Nacional o projeto $\mathrm{n}^{\circ}$ 148, de 1926, que instituía o "mandado de proteç̃̃o" "mandado de restauracão" contra les̃̃o ou amaça de

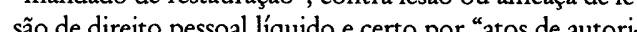

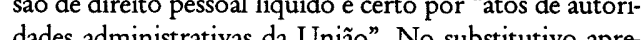
dades adinistrativas da Unián. No substitutivo apresentado pela Comissão de Justiça da Camara dos Deputados o art. $1^{\circ}$ ampliava o âmbito dos mandados, para dirigínão mais restritos, portanto, aos atos de autoridades administrativas da União. Quando das discussões que antecederam a Constituição de 1934 e que se iniciam com o anteprojeto da chamada Comissão do Itamaraty, João Mangabeira introduziu nesse anteprojeto norma instituindo o mandado de segurança para amparar "direito incontestavel ameaçado ou violado por ato manifestamente ilegal do Poder Executivo". A limitação que aí se estabelecia, restringindo o mandado de segurança a combater apenas atos ilegais do Poder Executivo, deu margem a inúmeras controvérsias, pretendendo alguns que a nova ação pudesse atingir atos de particulares e outros que abrangesse também atos inconstitucionais do Poder Legislativo. "Ato do Poder Público", "ato de autoridade pública", "ato "de qualquer autoridade ou do poder público" foram outras fórmulas sugeridas em diferentes emendas, ate firmarse a expressão "ato de qualquer autoridade", consignada pela primeira vez em emenda apresentada por Maurício Cardoso e Adroaldo Mesquita da Costa e incorporada, após, ao texto constitucional (Sobre a historia do mandado de segurança, por todos, Themístocles Brandão
Cavalcanti, Do Mandado de Segurança, Rio de Janeiro, 1936, Freitas Bastos, p. 239 e segs.)

A expressão "fuga para o direito privado" (Die Flucht in das Privatrecht) é de Fritz Fleiner (Institutionen des Destschen Verwaltungsrechts, Tübigen, 1928, $8^{\mathrm{a}}$ ed., J. C. B. Mohr, p. 326) e ganhou notoriedade e aceitação no direito alemão (veja-se, recentemente, Heiko Faber, Verwaltungsrecht, 1992, J. C. B. Mohr, Tübingen, p. 326). $\mathrm{Na}$ Europa o fenômeno adquire significação logo apos a primeira grande guerra, como se infere da observação de Fleiner. No Brasil, entrétanto, pode-se dizer que só depois da segunda grande guerra é que as sociedades de economia mista e as empresas públicas passam a ser comumente utilizadas, ao lado das autarquias, como formas de descentralização administrativa, que o Decreto-lei $\mathrm{n}^{\circ} 200$ de 25.02 .67 viria a designar como "administração indireta". As críticas e protestos da doutrina contra essa designação não impediram sua recepção nos textos constitucionais de $1969 \mathrm{e} 1988$. Quanto às fundações de direito privado instituídas e mantidas pelo Poder Público, embora elas fossem muito antigas no direito brasileiro (Clóvis Bevilácsua Código Civil dos Estados Unidos do Brasil Comenta, Rio de Janeiro, Rio, 1976, Brasil, Comentado, Rio de Janeiro, Rio, 1976, p. 241 Miguel Reale, Direito Administrativo, Rio de Janeiro, Forense, 1969, p. 17 e segs.), só mais recentemente é que administração indireta, ao lado das sociedades de econoadministração indireta, ao lado das sociedades de econo-
mia mista e das empresas públicas.

3 É sabido que no direito alemão, chegou-se a desenvolver econsolidar a noção da dupla personalidade do Estado. Ao tempo do Estado Absoluto ou do regime de polícia, a rigor o direito era apenas o direito privado. Assim o Estado que era atingido pelo direito, ou que a ele se submetia, era apenas o fisco - a caixa especial, o tesouro peculiar do monarca e do príncipe, mas não, como obser va Otto Mayer, "o Estado propriamente dito, a associação política, a pessoa jurídica de direito público". E pros-

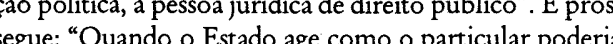
fazế-lo, quando o Estado age como o particular poderia

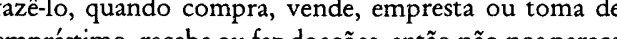
difíci

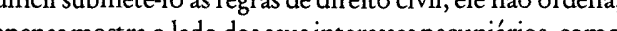
apenas mostra o lado dos seus interesses pecuniarios, como dizemos, e, por isto, se submete ao direito civil. Mas se, verdadeiramente, põe-se a comandar e a exercer o poder publico, então não se trata mais de aplicar o direito civil (LeDroit Administratif Allemand, Paris, Giard \& E. Brière, 1903, vol. I, p. 55 e segs; Deutsches Verwaltungsrecht, Berlin, Duncker \& Humblot, 1924, $3^{2}$ ed., 1924 e 1969, vol. I, p 41 e segs.). Por caminhos diferentes, o direito francês e o alemão chegaram, porém, a um ponto comum: só o Estado que é regido pelo Direito Público pratica atos de autoridade. Veja-se, abaixo, nota 16.

4 Cours de Droit Administratif, Faculté de Droit de Paris, Diplôme d'Etudes Superireures de Droit Public, Paris, 1953 p 70 ender 1952 1953, p. 70 e segs., apud Paul Sabourin, Recherches Sur la Notion d'Autorité Administrative en Droit Français, Pa-
ris, L. G. D. J., 1966, p. 65. obre isto, bem como sobre toda a evolução do conceide autoridade pública no direito francês que aqu raçamos seguindo-lhe os passos, Paul Sabourin, op. cit. 36.

raité Elémentaire de Droit Administratif, $12^{2}$ ed., 1930 15 e segs., apud Paul Sabourin, op. cit. p. 69 e 70 oud Paul Sabourin, op. cit. p. 47.

jeorge Vedel \& Pierre Delvolvé, Dorit Administratif is, Puf, 1992, vol. I, p. 239.

7. Vedel \& P. Delvolvé, op. e vol. cits, p. 240.

G. Vedel \& p. Delvolvé, op. cit., vol. II, p. 660

op. cit., vol. II, p. 661

"Também se consideram atos de autoridade os de estaecimentos públicos e de pessoas naturais ou jurídicas desempenho de serviços públicos, em virtude de deleão ou contrato exclusivo, ainda quando transgridam itrato ou exorbitem da delegação"

Os partidos político, no sistema da atual Constituição República, deixaram de ser pessoas jurídicas de direito alico, uma vez que adquirem "personalidade juŕlica forma a lei civil” (adq. 17, $\$ 2^{\circ}$ ) Creio estar juridica forma da lei civil" (art. 17, $\$ 2^{\circ}$ ). Creio estar revogado ntra os atos de órgãos dos partidos políticos não cabe ntra os atos de $i$ gios dos paridos politicos não cabe is, mandado de segurança, pois os partidos políticos, não exercem, de outra parte, função delegada do Ponão exercem,

Pareceres, Porto Alegre, Sulina, 1963, p. 18 e segs.

Hely Lopes Meirelles sustentou em vários pareceres, igos e livros de doutrina, que a regra a que tais entida estavam sujeitas era a de que "suas contratações são lizadas segundo o sistema da livre escolha", nada impe do, entretanto, que adotassem, se assim achassem coniiente, "a licitação formal do Decreto-Lei 200/67 ou t procedimento seletivo simplificado, estabelecido em ;ulamento ou constante de cada instrumento nvocatório, em conformidade com disposição atutária ou deliberação de sua Diretoria" (A Licitação ; Entidades Paraestatais, RF 261/49 e RDA 132/32 udos e Pareceres de Direito Público, RT, São Paulo, 31, v. III, p. 528-529). “A licitação só é obrigatória para contratações das entidades públicas - estatais contrataçoes das entidades publicas - estatais
árquicas - mas pode ser realizada pelas pessoas de direiarquicas - mas pode ser realizada pelas pessoas de direi-
privado como são as entidades paraestatais - sociedades privado como são as entidades paraestatais - sociedades se público, serviços sociais autônomos - desde que a le ecial o determine, ou conste de seus estatutos essa suão ou a diretoria da empresa assim o delibere" (Licita ie Contrato Administrativo, RT, São Paulo, 1973, p. . Tal tese, que resultou triunfante em vários julgados ; nossos tribunais (Hely Lopes Meirelles, Estudos e receres de Direito Público cit. p. 529) levou a que obras blicas de imenso valor fossem contratadas pela livre olha dos dirigentes de sociedades de economia mista empresses públicss guiados por critérios puramente jetivos e sem prévia selecão, portanto, por procedinto licitatório. $O$ escândalo provocado por alguma dessas contratações feitas sem a observância de qualquer padrões objetivos contribui, a par de sólidas razões doutrinárias, para gerar reação de prestigiosos doutrinadores do nosso Direito Administrativo, com Celso Antônio Bandeira de Mello à frente. Para o mestre paulista, na vigência da Emenda Constitucional n ${ }^{\circ} 1 / 69$ as sociedades de economia mista e as empresas públicas "não podem se esquivar a um procedimento licitatorio, salvo quando no exercício de atos tipicamente comerciais ligados as desempenho imediato de atividade industrial ou comercial que, por lei, lhes incumba desenvolver como objeto das finalidades para que foram criadas. Com efeito: entende-se que uma siderurgica estatal compre rotineiramente, mediante os procedimentos usuais no mercado, as partidas necessárias para al imentar sua produção e que por iguais processos venda seus produtos. Reversamente, se pretender equipar-se ou renovar seu equipamento produtor, deverá atender aos princípios da licitação".

A razão da sujeição dessas entidades da Administração Indireta aos princípio licitatórios estava, como está ainda, no respeito ao princípio maior da igualdade perante o esno respeito ao princípio maior da igualdade perante o es-
tado, ao princípio isonômico considerado o entendido da forma mais ampla possivel.

"Quem atua como instrumento do Estado" - observa o ilustre professor da PUC de São Paulo - "quem age na persecução de escopos assumidos por ele, quem pertence à administração indireta ou descentralizada, quem tem patrimônio formado total ou predominantemente pelo governo, não pode se eximir a tratar isonomicamente os administrados nem se subtrair aos procedimentos estabelecidos em ordem a buscar os negócios mais convenientes, decididos em um certame amplo e aberto." Mesmo porque, registra o mesmo autor, é oportuno recordar "que a parcela mais ponderável das obras e serviços públicos de monta se realiza por via dessa modalidade de pessoas governamentais. As grandes aquisições e contratos de obras públicas são realizadas precisamente por estas entidades. A admitir-se possam se esquivar às licitaç̃es, todo o mecanismo cautelar previsto para os contratos atinentes a empreendimentos deste jaez perderia seu principal objeto. Quer-se dizer: O Estado, graças ao concurso de sociedades mistas e empresas públicas, passaria ao largo das exigências de licitação a dizer, ficaria liberto de todo o mecanismo cautelar - concebido em vista de despesas maiores-precisamente no caso de numerosíssimos empreendimentos
1980 , p. 9 e segs).

16 Também no direito alemão "ato de autoridade" é considerado sinônimo de "ato de direito público", e mais especificamente, pela conotação de unilateralidade que possui, de "ato administrativo". A atividade da administração pública será "de autoridade" (bobeitliche), quando for regida pelo direito público ou, mais brevemente, for "de direito público" (öfentliche-rechtliche) (Hartmut Maurer, Allgemeines Verwaltungsrecht, München, C. H. Beck, 1982, p. 26; Ingo von Münch, in Erichsen/Martens, Allgemeines Verwaltungsrecht, Berlim, W. de Gruyter, 
1986, p. 14 e segs.; Norbert Achterberg, Allgemeines Verwaltungsrecht, Heidelberg, C.F. Müller, 1982, p. 336; Stelkens/Bonk/Sachs, Verwaltungsverfaberensgesetz, München, C.H. Beck, 1993, p. 679 e segs.).

17 Ainda ao tempo da Emenda Consich Justrivo de 1969, Tustrativo dessa orientação e acordãos da $1^{\text {a }}$ Turm TrR, AMS 108.891 - SP, re Mite 18 Alfred Katz, Staatsrecht, Heidelberg, C. F. Müller, 1992, 49

19 Robert Post, Theories of Constitutional Interpretation in Law and the Order of Culture, Berkeley, University of California Press, 1991, p. 13 e segs. Observa Post que a expressão "responsive interpretation" provém da noção estabelecida por Phelippe Nonet e Philip Selznick de "responsive law", ou seja a lei que funciona "as a facilitator of response to social needes and aspirations" (p. $24 \mathrm{e} \mathrm{p}$. 39 , nota 63)

20 Katz, op. e p. cit.

21 Comentário ao CPC, vol. V, p. 156-157.

22 Do Mandado de segurança, Rio, Forense, 1993, p. 151 e 156.

23 O Controle dos Atos Administrativos pelo Poder Judiciário, p. 338.

24 STJ, 1ª Seção, MS 591 - DF, DJU 4.03.91, p. 1.959) ou que "o juizo competente para processar e julgar o mandado de seguraņ̧ é o da sede da auloridade coatora "RTFR 132/ $359 \mathrm{e}$, igualmente, RSTJ $2 / 347$, RTFR $119 / 26,132 / 243$, 132/266, 134/35, 160/227, cf. Theotônio Negrão, CPC e
Legislação Processual em Vigor, $25^{\text {a }}$ ed., p. 1117, notas ao art. 14 da Lei do MS.

25 Lúcia Valle Figueiredo, em conferência que proferiu obre Autoridade Coatora e Sujeito Passivo, (in Manda do de Segurança, Porto Alegre, 1986, Sérgio Antônio $\mathrm{Fa}$ bris, p. 21 e segs.) narra um desses expedientes, que surpreendeu em sua prática como Juiz Federal. Diz a consagrada administrativista: "Outro problema que se colocou esse bastante sério, foi o do Empréstimo Compulsório. Neste, deliberadamente, as autoridades administrativas, que legis lam, resolveram impossibilitar a interposição de mandado de segurança, por meio do art. 7 do Decreto-Lei: "Cabe ao Ministro da Fazenda praticar os atos necessários à execuça deste Decreto-Lei e ao Secretário da Receita Federal expedir os avisos de cobranca do Empréstimo". Com isso, o Ministro da Fazenda praticaria os atos necessários à execusão do De creto-Lei. O Ministro da Fazenda é autoridade sediada em Brasilia. Com seu tumo seria o Secretário da Receita Fedo ral que expediria avisos de cobransa do Emṕrtimo. Com isso se pretendia deslocar também ga do Empréstimo. Com via de mandado de seguranca qualquer interposiçáo, por viário mandado de seguranca, contra o malsinato compul donte Euidente. Se pensaren na extensao do Brasil, é evidente que está, por exemplo, sediado no Acre, não va impetrar um mandado de segurança em Brasilia, ainda mais se não se tratar de quantia vultosa. Se a quantia for um pou co mais módica, é evidente que esse mandado de seguran não seria interposto. Pretendia-se afastar a amplitude, magnitude do mandado de seguran fa".

\section{causas da revisão dos contratos pelo juiz e o digo de Defesa do Consumidor}

\section{Renato Ferreira da Silva}

'gado em Porto Alegre. Mestre em Direito pela UFRGS.

IRIO

odução; 1. A revisão dos contratos e as relações do Código de Proteção e Defesa do Consumidor; 2. Plano de ho; II - O conceito de autonomia da vontade: visão clássica e moderna; A) Visão clássica; 3 - A teoria de $\mathrm{E}$. - A 7 - O e tual, 7 -O fere re ma da o dos princípios, 12 - A moderna liberdade contratual; 13 - O moderno efeito relativo, 14 - As modernas retaçăo e execução, 15. Os novos limites à autonomia contratual; $11 \mathrm{l}$ - Causas de revisão concomitantes ;ão do contrato; A) Clausulas Abusivas; 16 - Fundamento do rol do art. 51 do CDC; 17 - Natureza do vício o pelas cláusulas abusivas; 18 - Efeito da presença das cláusulas; 19 - Revisão pelo juiz; 20 - A interpretação ttiva e o procedimento revisional; B) Lesão enorme; 21 - Conceito de lesão; 22 - $O$ acolhimento da lesão pelo 23 - Âmbito de aplicação do instituto; 24 - Revisão e lesão; IV - Causas de revisão supervenientes à contratação; sria da imprevisão; 25 - Caráter clássico da teoria e requisito da imprevisibilidade; 26 - Outros requisitos; $\mathrm{B}$ ) da base do negócio; 27 - Diferenças entre as teorias; 28 - A base objetiva; 29 - Revisão e teoria da base.

\section{bstract}

arting from the hypotheses that (a) we are through a trasition in which the courts, the ine and the law, itself begin of treaf the ility of the judicial revision of contracts sely and that (b) there are several juridical ss that can anable this activity of the judge's, esent paper studies the institutes which give for the judicial revision of contracts at the mer law.

wo groups of institutes that allow the on are analysed. The first group consists in incomitant causes to contract formation he second group is the one which refers to pearance of causes supervenient to contract ation.

\section{- Introdução}

O tema da revisibilidade de cláusulas atuais por atividade do juiz ganhou novo impulso com o advento da lei de defesa dos consumidores. Classicamente, o assunto é versado dentro dos parâmetros da contratualística oitocentista, cingida sempre pelo forte caráte individual e liberal. Dentro daquele contexto as oportunidades para que se desse uma atividade revisora eram muito limitadas.

Não obstante estas limitações, algumas circunstâncias afloravam como permissivas da revisão judicial, sempre que se verificasse um fato futuro e imprevisível que alterasse a economia negocial. Uma visão diferente (a) do próprio conceito de obrigação e (b) da noção da autonomia privada acarreta, modernamente, uma ampliação das situações de revisão, agregando-se aos fatos futuros e imprevisíveis, os futuros e previsíveis, mas frustradores do contrato, bem como fatos concomitantes à pró pria formação do pacto que ensejam a lesão enorme ou a presença de cláusulas abusivas.

Estas figuras, graças a esforços que ainda são levados a cabo, adentram a seara do direito civil comum, como fruto de construções dou- 